\title{
Design and implementation of an impressed current cathodic protection system for buried metallic pipes (part II) (considering Al-Quds gas station in Baghdad)
}

Saif Aldeen H. Mohammed, Isam M. Abdulbaqi

Electrical Engineering Department, College of Engineering, Mustansiriah University, Iraq

\begin{tabular}{l} 
Article Info \\
\hline Article history: \\
Received May 24, 2019 \\
Revised Jul 8, 2019 \\
Accepted Oct 12, 2019 \\
\hline Keywords: \\
CU-CUSO 4 \\
Impressed current \\
NACE cathodic protection \\
standard \\
The reference electrode \\
\\
Corresponding Author: \\
Saif Aldeen H. Mohammed, \\
Electrical Engineering Department, \\
Mustanisirah University, \\
Baghdad, Iraq. \\
Email: saiyyouf@yahoo.com
\end{tabular}

\begin{abstract}
In this part, the implementation of the Cathodic Protection (CP) station in a new position is done due to the analytical study of the part (I) [1]. Also, a PV fed self-adjusted DC-DC converter is designed and implemented for this purpose, and Aluminum anodes designed and manufactured for the sake of approving the proposed CP station operation. A field test shows enhanced results due to the National Association of Corrosion Engineering NACE standard. An edit has been made on the main empirical formula that is previously intended for the design of the same CP system. The proposed CP station is very flexible, more accurate, of lower cost, and needs little maintenance as compared with the already existing $\mathrm{CP}$ station.
\end{abstract}

This is an open access article under the CC BY-SA license.

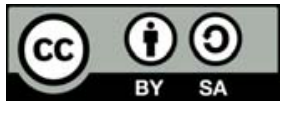

Corresponding Author:

Electrical Engineering Department, Baghdad, Iraq.

Email. saiyyouf@yahoo.com

\section{INTRODUCTION}

The cathodic protection (CP) is a technique that is used to protect metallic pipes; buried in soil, from corrosion. There are two types of CP systems; sacrificial anode and impressed current. In the sacrificial anode, there is no power supply feeding the system. While an impressed current CP system includes a DC source fed from PV panel or from an AC source followed by rectifier arrangements, depending on the availability of each of them. The studied CP system in this work is that of "Al-Quds Gas Station" which composed of two CP stations located at the two ends of the $6000 \mathrm{~m}$ buried pipe used for carrying raw water for cooling purposes of the gas station. The choice of stations position has been done due to the availability of the electric power AC supply at both ends of the pipe, the intake end, and the gas station end [1].

The work includes the choice of the new position of the CP station depending on the map of the pipeline, such that it must be the most effective one. The DC-DC converter; fed from a battery charged from a solar PV system, is designed. The terminal voltage of this converter varies automatically due to the feedback signal of the standard electrode measurement such that it will keep the pipe continuously protected. Aluminium anodes are designed and manufactured for the sake of using them in the real test of the new station position.

The obtained results declare that all the test points readings are within the standard NACE range. A modification on the constant of the available empirical design equation that measures the anode to earth 
resistance $\left(R_{h}\right)$ has been done. The PV fed station shows more accurate protection, flexibility and of lower cost than the traditional design.

\section{THEORETICAL BACKGROUND}

The available information about the design of the CP system in Al-Quds Gas Station is no more than a number of empirical design equations and data in standard tables. The available empirical design equations are $[2,3]$ :

$$
\begin{aligned}
& A=\pi \times D \times L \\
& I=A \times J \times C E \\
& N=I / I_{a} \\
& R_{c}=2500 / A \\
& R_{h}=\left(\frac{0.00521 \rho}{N \times L_{h}}\right)\left(\ln \left(\frac{4 L_{h}{ }^{2}+4 L_{h} \sqrt{S^{2}+L_{h}{ }^{2}}}{d \times S}\right)+\frac{S}{L_{h}}-\frac{\sqrt{S^{2}+L_{h}{ }^{2}}}{L_{h}}-1\right) \\
& R_{t}=R_{h}+R_{c}+R_{w} \\
& V_{t}=I \times R_{t} \times 1,5
\end{aligned}
$$

Where:

A: surface area of the pipe $\left(\mathrm{ft}^{2}\right)$

I: total current for CP (A)

$N$ : number of required anodes

$R_{h}$ : anode to earth resistance $(\Omega)$

$S$ : twice anode depth (ft)

$V_{t}$ : terminal voltage $(\mathrm{V})$

\section{$D$ : pipe diameter (ft)}

$J$ : required current density $\left(\mathrm{A} \cdot \mathrm{ft}^{-2}\right)$

$I_{a}$ : max. anode current (A)

$\rho:$ soil resistivity $(\Omega \cdot \mathrm{cm})$

$d$ : anode diameter $(\mathrm{ft})$

$R_{t}$ : total resistance $(\Omega)$
$L$ : pipe length (ft)

$C E$ : coating efficiency

$R_{c}$ : coating resistance $(\Omega)$

$L_{h}$ : anode bed length (ft)

$R_{w}$ : required cables resistance $(\Omega)$

The above equations are suitable to calculate the required terminal voltage and current of the DC power supply feeding certain typical CP system, depending on its already exists and assumed data only. Such empirical equations cannot cover all the practical situation problems, such as the existence of a river or swamp or the bends in the pipeline path ... etc. The National Association of Corrosion Engineering (NACE) shows that the international CP standard for pipelines states that $[4,5,6]$

"The required electrical potential for protection of a carbon steel pipe must vary from $(-0.85 \mathrm{~V})$ to $(-1.2 \mathrm{~V})$ against ((CU-CUSO 4$)$ reference electrode); otherwise, the corrosion is happening". By this criterion, the pipe can be considered as a protected pipe from corrosion or not.

The PV panels are used to feed the smart charger; so that, the required charging process is done for the batteries during the day. This is, for making them ready to work during the night or at times when the weather is cloudy. Hence, the CP system battery bank must be able to feed it for at least 16 hours. A set of batteries of specific capacity are connected either in series or parallel to feed a DC-DC converter to set the input voltage at a level due to the requirements of the CP system. So, it is a step-down converter (buck converter).

The photovoltaic PV panel is an energy source that converts the sunlight energy to electrical energy. It is not like a traditional DC source, it is neither the same as a DC voltage source nor DC current source, such that its external characteristics composed of both of them. This behaviour is influenced by light intensity and ambient temperature $[7,8]$.

Generally, the charging current of batteries must not lead to overcharging or gassing or rising in temperature. At the beginning of the charging, the process can be done with a relatively high current until it is reached to a safe limit of the battery or in the case of the battery state is near from the fully charged. The relation between the charging current with the charging time is as follows [9]:

$$
I_{c h}=A_{h} e^{-\tau}
$$
charging time.

Where $I_{c h}$ is the charging current, $A_{h}$ is the Ampere-hours of the battery, and $\tau$ represents the

The choice of the batteries depends on the ampere-hour required to supply the load. For example, if we have a load of $10 \mathrm{~A}, 24 \mathrm{~V}$ for 20 hours of duty, then, two batteries of 200 ampere-hours, $12 \mathrm{~V}$ are connected in series are used for this purpose. Usually, the battery bank used in the PV power system as a storage device 
for electrical energy produced by the PV panel during the daylight and feeding the loads during the night. Also, using of battery bank leads to make the PV system more stable; such that, the surplus power problem or the reduction in the supplied power due to change in weather conditions can be solved [10].

The lead-acid battery is the most popular choice in the PV power system due to many reasons like its low cost, availability in different sizes, good high rate performance etc $[10,11]$. The gelled lead-acid battery is one kind of lead-acid battery in which the electrolyte is diluted sulfuric acid $\left(\mathrm{H}_{2} \mathrm{SO}_{4}\right)$ solution. This electrolyte solution is gelled by adding the silicon dioxide $\left(\mathrm{SiO}_{2}\right)$ to it. In this design of batteries, it is used as an internal recombination technique to return the oxygen and hydrogen gasses through the gassing process to water $[10,12]$. Hence, this design will minimize the losses of electrolyte and it doesn't require to replenish of electrolyte solution to battery $[12,13]$.

In the buck converter, the output voltage is converted to a level that is smaller than the input voltage. The basic circuit of the buck converter is shown in Figure $1[14,15]$. The buck converter works in two operation modes: continuous conduction mode and discontinuous conduction mode $[16,17,18]$.

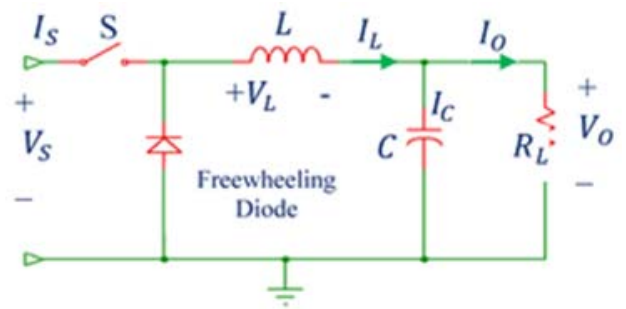

Figure 1. A basic circuit of a buck converter

The anode is of a high priority in the CP system design. It is a drain pole that redirects the conventional current and receives the electrons from the defect spots on the pipe coating in order to protect it from corrosion [1]. The anode connected to the positive output terminal of the DC-DC converter. There are many types of materials used in manufacturing the anode such as Graphite anodes, Iron-Silicon anodes, Silver-Lead anodes, Silicon-Chromium-Cast Iron and Titanium anodes coated with Metal Oxides [4]. Every one of these types is used according to the nature of the soil, the length of the pipe to be protected and the life span for the CP system $[4,19]$.

There are many types of anodes design, one of them depends on how many years that anode can withstand with an acceptable availability, the total current and the anode weight as in the following formula [20]:

$$
t=\frac{W \times n \times F}{M \times I_{a}}
$$

Where:

$t$ : The anode life in second, $W$ : Anode weight in grams, $\mathrm{n}$ : The number of electrons transferred (the valence), $F$ : Faraday's number and M: Atomic weight of the metal (grams/ mole).

The place; that anodes are contained inside the soil, is called anode ground beds. There are two types of these anode ground beds, shallow ground beds, and deep ground beds. Shallow ground beds preferred when the soil resistivity is low. Anodes are installed horizontally or vertically for a depth of about 2 $\mathrm{m}$, then it covered with a coke breeze. This method is more economical, easy to install and the process of exchanging anodes is simple $[21,22]$.

The soil is the conduction path in which the electrons transfer from the cathode to the anode of the CP system. It is considered as an electrolyte medium between these electrical pols [4]. Because it is not a homogeneous mixture and it differs for different places, the soil has an uneven influence on the pipe. There are many types of soil such as muddy, sandy and rocky, which has a main effect on the corrosion process that is reflected in the design of the CP system. For every type of environment, there is a range of a current density related to [23]. The wide range of the current density is due to the soil nature, porosity and humidity which have a larger effect on the soil [19]. The soil humidity is changed according to weather conditions or land irrigation for agricultural purposes. The variation in the humidity of the soil leads to change the soil resistivity, which leads to change the current passes through the circuit. From here, the need of the continuous changing for the applied voltage in the CP system; via the use of the reference electrode as mentioned, has a very important impact on keeping the pipe in safe $[4,7,19]$.

Design and implementation of an impressed current cathodic protection system for ... (Saif Aldeen $\mathrm{H}$ ) 


\section{THE OVERALL SIZING OF THE PROPOSED CP SYSTEM}

The pipe details at Al-Quds Gas Station are the 6000m length, 8-inch in diameter and $8 \mathrm{~mm}$ in thickness [1], and from the empirical equations of the CP design above, we get:

$$
L=6000 \mathrm{~m} \times \frac{3.28 \mathrm{ft}}{\mathrm{m}}=19685.04 \mathrm{ft} \text { and } D=8 \mathrm{inch} \times \frac{1}{12} \mathrm{ft} / \mathrm{inch}=0.6667 \mathrm{ft}
$$

From (1) we get: $A=\pi \times D \times L=\pi \times 0.6667 \times 19685.04=41228.25 \mathrm{ft}^{2}$

Current density $J=0.002 \mathrm{~A}^{\mathrm{ft}}{ }^{-2}[23]$. Now, from (2) the applied current can be calculated as $I=A \times J \times$ $(1-\eta)$ where $\eta$ is the coating efficiency $=0.9$ [24]. Then, $I=41228.25 \times 0.002 \times(1-0.9)=8.245 \mathrm{~A}$ is the required current.

The required anodes number $N$ is determined from (3) and $I_{a}=2.5 \mathrm{~A}$ (from the practical anode design section):

$$
N=\frac{I}{I_{a}}=\frac{8.245}{2.5}=3.2 \rightarrow N=4
$$

$\rho=1400 \Omega . \mathrm{cm}$ [18], the anode length $L_{h}=1 \mathrm{~m} \times 3.28 \mathrm{ft} / \mathrm{m}=3.28 \mathrm{ft}$, the twice anode depth $S=2 \mathrm{~m} \times$ $3.28 \mathrm{ft} / \mathrm{m}=6.56 \mathrm{ft}$ and $d=0.04 \mathrm{~m} \times 3.28 \mathrm{ft} / \mathrm{m}=0.1312 \mathrm{ft}$.

Now, sub in (5) to find the anode to earth resistance $R_{h}$ : then, $R_{h}=2.1405 \Omega$

Also, from (4) to find the coating resistance:

$$
R_{c}=\frac{2500}{\mathrm{~A}}=\frac{2500}{41228.25}=0.0606 \Omega
$$

From the used wire specification $\mathrm{R}_{\mathrm{w}}=0.285 \Omega$. Now, from (6) and (7) we get:

$$
\begin{aligned}
& R_{t}=R_{h}+R_{c}+R_{w}=2.1405+0.0606+0.285 . \text { then, } R_{t}=2.4861 \Omega \\
& V_{t}=I \times R_{t} \times 1,5=8.245 \times 2.4861 \times 1.5=30.746 \mathrm{~V} \therefore P_{t}=30.746 \times 8.245=253.5 \mathrm{~W}
\end{aligned}
$$

The CP load is $253.5 \mathrm{~W}$. So, the proposed buck converter must cover this load. Hence, it's rated is of $24 \mathrm{~V}, 15 \mathrm{~A}$, and $360 \mathrm{~W}$ in order to overcome all the variable conditions of the CP site.

The battery bank contains two batteries of a gelled lead-acid type. The rated of each battery is $12 \mathrm{~V}$, $200 \mathrm{Ah}$, and the deep discharge current is $20 \mathrm{~A}$. These two batteries are connected in series to provide $24 \mathrm{~V}$ and 200Ah. The connection of the solar CP power system is shown in Figure 2, such that the PV panel fed the smart charger input. While the smart charger output, the battery bank and the DC-DC converter fed the CP load, are all connected in parallel.

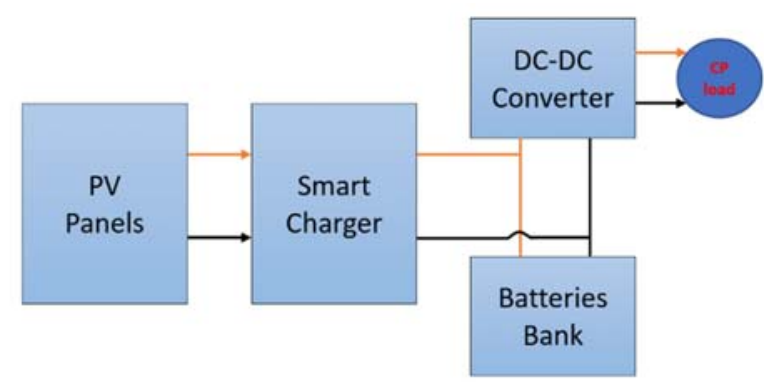

Figure 2. The typical connection of the solar CP system

The PV panels and the smart charger must supply both, the charging currents for the batteries, and the CP load current during the daylight period of say 8 hours. At night, the batteries supply the CP load current for 16 hours. So, the load current of $15 \mathrm{~A}$ (this absorbed from the batteries for 16 hours at night) must be substituted at the daylight with the double value during 8 hours. This leads to conclude that the PV panels must supply a current of $45 \mathrm{~A}$ (15A for the $\mathrm{CP}$ load and the batteries charging current of $30 \mathrm{~A}$ at the same time). The data of the available PV panel is $24 \mathrm{~V}, 8.5 \mathrm{~A}$ for $700 \mathrm{~W} / \mathrm{m}^{2}$ and $250 \mathrm{~W}$ nominal power. Hence, the required PV panels are: $\frac{45}{8.5}=5.29 \cong 6$

Int J Pow Elec \& Dri Syst Vol. 11, No. 1, Mar 2020 : 275 - 283 
So, the number of PV panels required is 6 panels connected in parallel. The overall system sizing will be as in Table 1:

Table 1. The sizing of the proposed CP system

\begin{tabular}{lcc}
\hline Component & Number & Rated value \\
\hline PV panel & 6 & $24 \mathrm{~V}, 250 \mathrm{~W}$ nominal power \\
Smart charger & 1 & $24 \mathrm{~V}, 45 \mathrm{~A}$ \\
Batteries & 2 & $12 \mathrm{~V}, 200 \mathrm{Ah}$ \\
Buck converter & 1 & $24 \mathrm{~V}, 15 \mathrm{~A}$ \\
Anodes & 4 & $1 \mathrm{~m}$ length, 4cm in diameter \\
\hline
\end{tabular}

\section{DESIGN OF THE PROPOSED CP SYSTEM}

\subsection{Anode design}

The material used in the practical design of the anode is the Aluminum as shown in Figure 3-a, because of its availability in the local markets and the ease of construction. The standard anode is a hollow cylinder and the thickness of this hollow cylinder anode to be designed is $1 \mathrm{~cm}$ [19]. Then the effective volume is the difference between the outer and the inner volumes. The hollow cylinder is shown in Figure 3-b is as follows:

$$
\begin{gathered}
r_{\text {outer }}=0.02 \mathrm{~m} \text { and } r_{\text {inner }}=0.01 \mathrm{~m}, \text { Cylinder volume }=\pi \times r^{2} \times \text { hight } \\
V_{\text {outer }}=\pi \times(0.02)^{2} \times 1=1.256 \times 10^{-3} \mathrm{~m}^{3} \text { and } V_{\text {inner }}=\pi \times(0.01)^{2} \times 1=3.141 \times 10^{-4} \mathrm{~m}^{3} \\
V_{\text {effevtive }}=V_{\text {outer }}-V_{\text {inner }}=9.426 \times 10^{-4} \mathrm{~m}^{3} \\
W_{\text {effevtive }}=\rho_{v} \times V_{\text {effevtive }}=2.545 \mathrm{~kg}=2545 \text { grams, } \rho_{v}=2700 \mathrm{~kg} / \mathrm{m}^{3} \text { for Aluminum [25]. } \\
\text { Since, } n=3, F=96500 \text { A.s } / \text { mole, } M=26.98 \mathrm{~g} / \mathrm{mole} \text {, and let } I=2.5 \mathrm{~A} \text {. Now use (9) to find the anode lifetime: } \\
t=\frac{W \times n \times F}{I \times M}=\frac{2545 \times 3 \times 96500}{2.5 \times 26.98}=3.46 \times 10^{6} \mathrm{~s}=1.385 \text { months }
\end{gathered}
$$

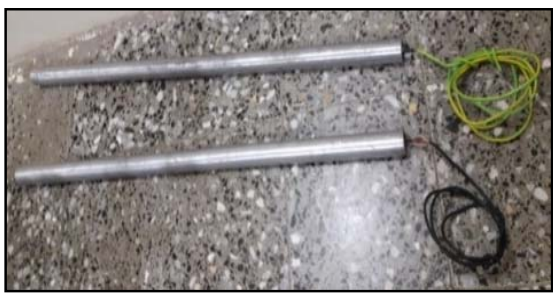

(a)

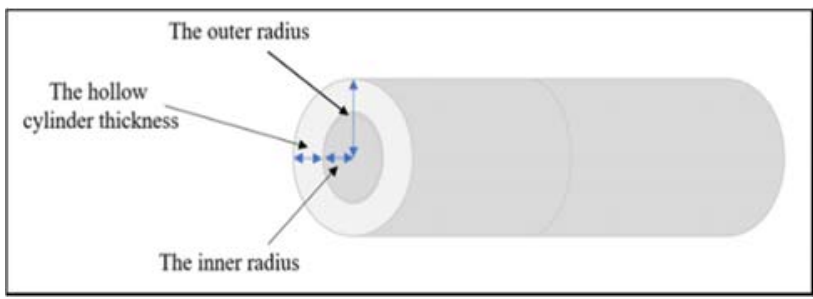

(b)

Figure 3. (a) The Aluminum anode. (b) The anode to be designed.

\subsection{DC-DC converter design}

The simulation block diagram of all components of the proposed buck converter in Proteus is shown in Figure 4-a. The designed and implemented buck converter is shown in Figure 4-b. A "heat run" test is done on this converter by a purely resistive load. During this test, the converter feeding the load by $14 \mathrm{~A}, 24 \mathrm{~V}$ continuously for 3 hours. The converter seems to be able to withstand the load. The oscilloscope shows the PWM signal of the microcontroller Arduino Nano practically that is used for the switching process of the MOSFET at a frequency of $31.25 \mathrm{kHz}$. as shown in Figure 5-a. The PWM signal of the Arduino Nano is fed to the PC817 and then, it is modified by MC34151 as shown in Figure 5-b and Figure 5-c. The output signal of MC34151 is supplied to the gate of the MOSFET. The waveform of the drain to source for the MOSFET used is shown in Figure 5-d. 


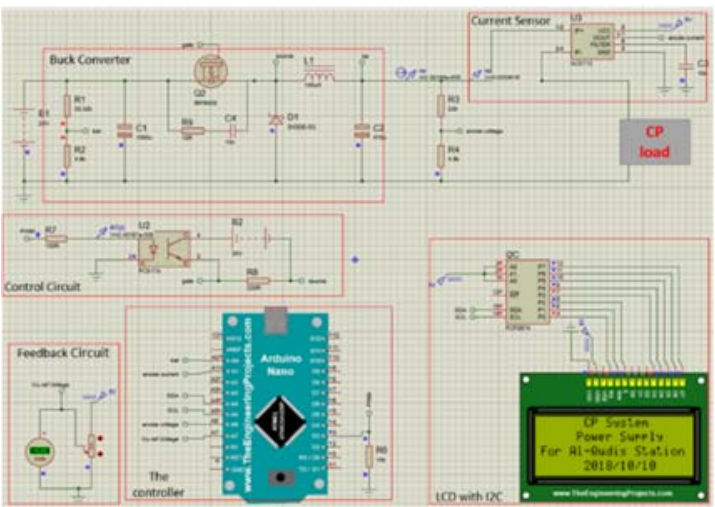

(a)

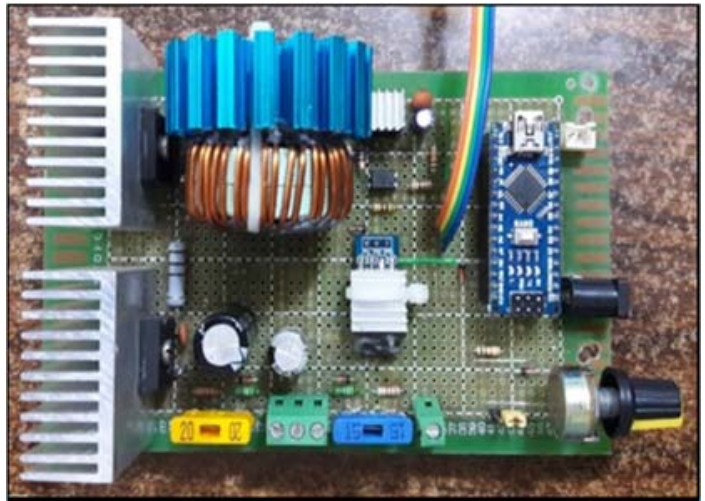

(b)

Figure 4. (a) Simulation block diagram of the proposed buck converter (b) The buck converter

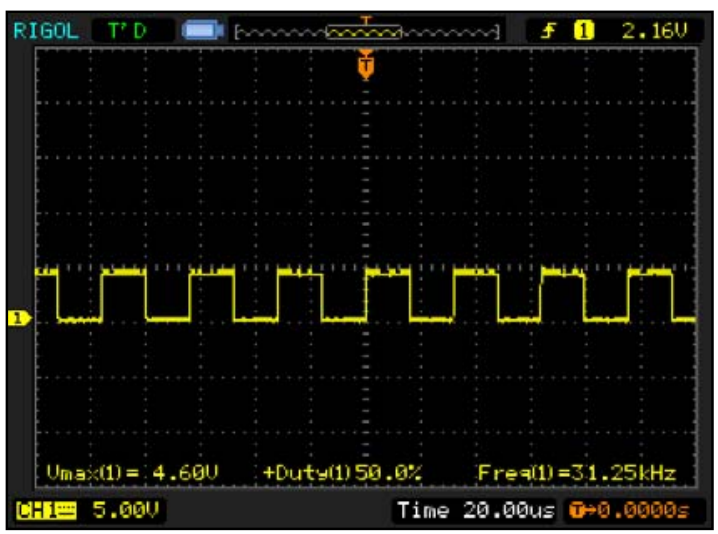

(a)

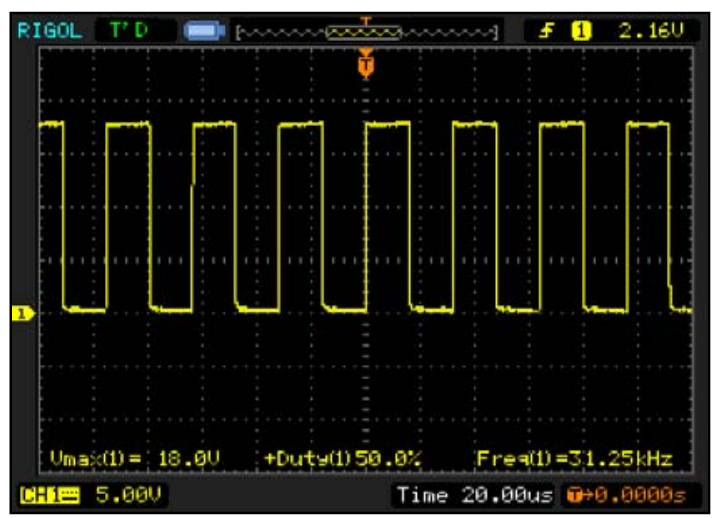

(c)

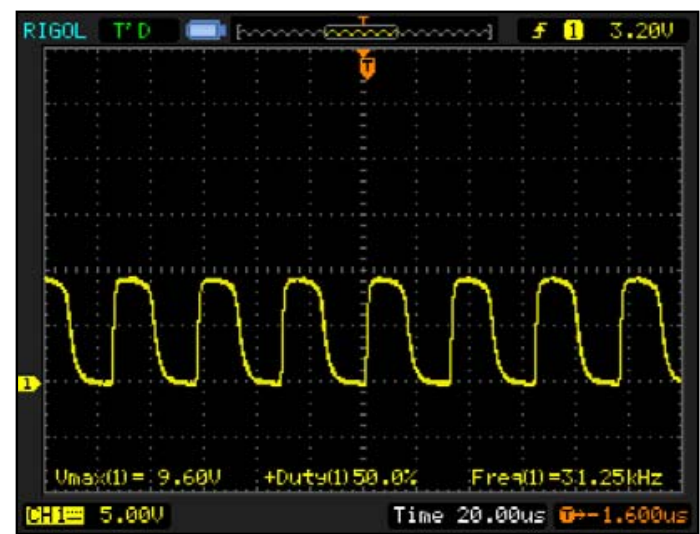

(b)

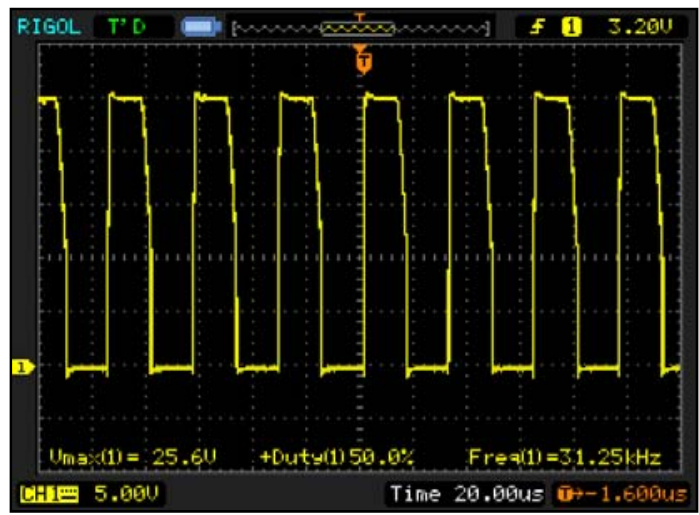

(d)

Figure 5. (a) the PWM signal of the Arduino Nano (b) the output signal of the PC817 (c) the output signal of the MC34151 (d) the drain to source voltage

The designed converter of the CP system is contained in a waterproof IP65 control box. Two fuses of $15 \mathrm{~A}$ with two circuit breakers are added for protection purposes, a fan is used for cooling the converter parts. The proposed solar CP station composed of the following parts shown in Figure 6. 


\section{THE FIELD EXPERIMENT}

Figure 7 shows the experiment site, the position of anode beds and the three test points which are considered to check the system activity. In this experiment, four Aluminum anodes as that shown in Figure 3 are connected with the field control board of the CP system and buried in a shallow anode ground beds of $5 \mathrm{~m}$ in length, $0.5 \mathrm{~m}$ width and $1 \mathrm{~m}$ depth. These anodes were covered in the anode beds by a mixture of salt and coke dust, and a lot of water is flowed down to increase the conductivity of the anode beds. The position of the anode ground beds chosen to be at a distance of $100 \mathrm{~m}$ far from the second test point on the pipe (as will be explained later).

The control board of the CP system start feeding $23 \mathrm{~V}$ and the applied current reaches $8.5 \mathrm{~A}$ during the test period, which elapsed two hours. This value of current is very close to that calculated due to (2), of 8.245A.

Now, to check out the system activity, the measurement with the reference electrode (CU-CUSO $)_{4}$ for the test points mentioned in Figure 7. The readings are as in Table 2. It is noticed that all the test points voltages in Table 2 , are within the standard protection range of $(-0.85 \mathrm{~V})$ to $(-1.2 \mathrm{~V})$. This means that the criteria of the cathodic protection are reached and the proposed CP system able to protect the pipe.

Table 2. The potential of the test points

\begin{tabular}{ccc}
\hline Test point & Its Position & The potential $(\mathrm{V})$ \\
\hline 1 & Near the station & -0.85 \\
2 & Near the experiment site & -1.13 \\
3 & Near the intake & -1.014 \\
\hline
\end{tabular}

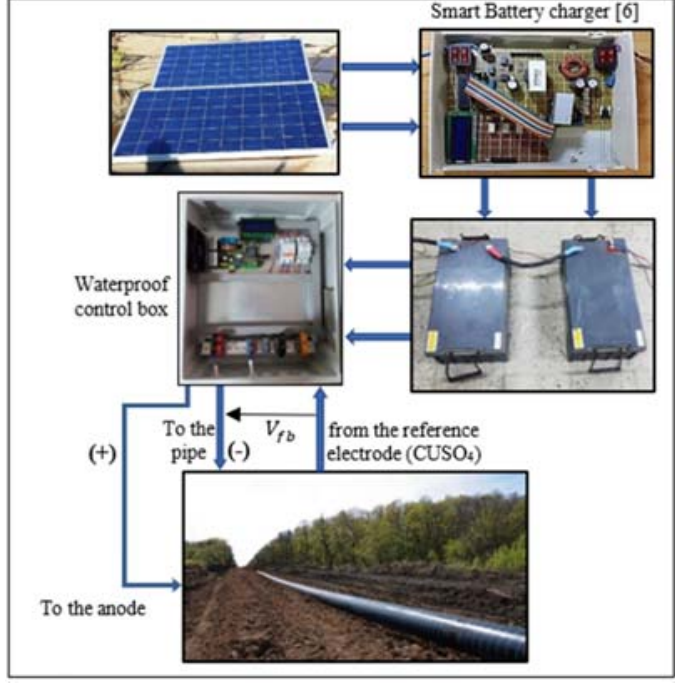

Figure 6. the proposed solar CP station parts

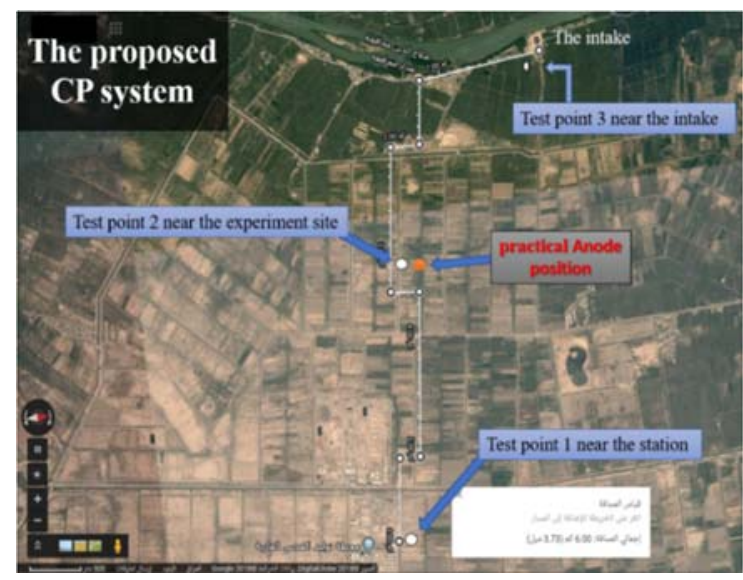

Figure 7. the position of anode beds and test points of the proposed CP system

\section{DISCUSSION}

The results of ANSYS [1] gives an important indication for putting the anode in the right position that leads to performing required protection. So, this position which is far of one third the pipe length from the pipe center must be considered. But practically, it is difficult to maintain this. Consider our case study of Al-Quds Gas Station, the pipe length is of $6000 \mathrm{~m}$ so, if the ANSYS results are adopted, the anodes must be buried at $2000 \mathrm{~m}$ far from the pipe. It is impractical to install a wire of $2000 \mathrm{~m}$ to connect these anodes and the pipe to the CP power supply. A costly, wide cross-sectional area wire must be used in order to reduce the voltage drop. Hence, the proposed distance of $100 \mathrm{~m}$ is considered in this test.

The (5) of the anode to earth resistance is modified according to the results of the field experiment which leads to enhance the design of the $\mathrm{CP}$ system and reached an acceptable performance. The modification on (5) is in the factor 0.00521 such that all other factors as $\left(\rho, L_{h}, N, d, S\right)$ are constants. From the voltage and current supplied to the CP load of the field practical experiment, the total resistance can be calculated as follows: 


$$
\begin{aligned}
& R_{t}=\frac{V_{t}}{I_{t}}=\frac{23}{8.5}=2.7 \Omega \text { sub this value of } R_{t} \text { in }(6) \text { to find } R_{h}: \\
& R_{t}=R_{h}+R_{c}+R_{w}, R_{c}=0.0606 \Omega \text { and } \mathrm{R}_{\mathrm{w}}=0.285 \Omega, \text { then: } R_{h}=2.3544 \Omega
\end{aligned}
$$

Now the number of anodes used $N=4, L_{h}=3.28 \mathrm{ft}, S=6.56 \mathrm{ft}, d=0.1312 \mathrm{ft}$ and $R_{h}=2.3544 \Omega$. Substitute all these factors in (5) results in:

$$
2.3544=\left(\frac{X \times 1400}{4 \times 3.28}\right)\left(\ln \left(\frac{4 \times 3.28^{2}+4 \times 3.28 \times \sqrt{6.56^{2}+3.28^{2}}}{0.1312 \times 6.56}\right)+\frac{6.56}{3.28}-\frac{\sqrt{6.56^{2}+3.28^{2}}}{3.28}-1\right) \therefore \boldsymbol{X}=\mathbf{0 . 0 0 5 7 3 0 4}
$$

So, the modified equation will be as:

$$
R_{h}=\left(\frac{\mathbf{0 . 0 0 5 7 3 0 4} \rho}{N \times L_{h}}\right)\left(\ln \left(\frac{4 L_{h}{ }^{2}+4 L_{h} \sqrt{S^{2}+L_{h}^{2}}}{d \times S}\right)+\frac{S}{L_{h}}-\frac{\sqrt{S^{2}+L_{h}^{2}}}{L_{h}}-1\right)
$$

\section{CONCLUSION}

The main conclusion of this work can be clarified in the following points:

First, due to the flexibility in choosing the anode position that is giving the best coverage of protection, a solar CP system must be used in order not to adhere to the electrical power sources. Second, the designed converter performs a continuous change of the applied anode to cathode voltage according to the feedback from the (CU-CUSO 4 reference electrode). Lastly, the total cost of the solar CP system is lower than that of the traditional CP system at Al-Quds Gas station. The solar CP system needs only 4 anodes instead of using 20 anodes in the traditional CP system.

\section{REFERENCES}

[1] Saif aldeen H. Mohammed, and Isam M. Abdulbaqi, "Numerical Study and Design of an Impressed Current Cathodic Protection System for Buried Metallic Pipes", Third Scientific Conference of Electrical Engineering (SCEE), IEEE, pp. 95-100, 2018.

[2] MESA Products, "Shallow Horizontal Continuous Ground Bed Design", C. P. Design center by MESA products, Inc, www.mesaproducts.com, 2001.

[3] H. B. Dwight. "Calculation of Resistances to Ground", in Transactions of the American Institute of Electrical Engineers, Vol. 55, No. 12, pp. 1319-1328, 1936.

[4] Peabody, Arland Wentworth, "Control of pipeline corrosion", Houston, Texas, National Association of corrosion engineers, 1967.

[5] Zaki Ahmad. "Principles of corrosion engineering and corrosion control", Elsevier Science \& Technology Books, 2006.

[6] PT INDOCAST FRANSASIA SEJAHTERA company website http://fransasia-s.com/criteria-for-cathodicprotection.

[7] Esraa M. Ismail. "Design, Simulation and Implementation of a Maximum Power Point Tracking System for Photovoltaic Panel Feeding Three-Phase Balanced Load", M.Sc. thesis presented to Mustansiriyah University, Iraq, 2016.

[8] Dola Sinha, Amiya Bandhu Das, Dipak Kr. Dhak, and Pradip Kr. Sadhu. "Equivalent Circuit Configuration for Solar PV Cell", International Conference on Non-Conventional Energy (ICONCE), pp. 58-60, 2014.

[9] David Linden and Thomas B. Reddy. "Handbook of Batteries", Third Edition, The McGraw-Hill Companies, Inc., The United States of America, 2002.

[10] Ola Subhi Waheed Al-Qasem. "Modeling and Simulation of Lead- Acid Storage Batteries within Photovoltaic Power Systems", M.Sc. thesis presented to the An-Najah National University, Palestine, 2012.

[11] Atiqah Hamizah Mohd Nordin and Ahmad Maliki Omar. "Modeling and Simulation of Photovoltaic (PV) Array and Maximum Power Point Tracker (MPPT) for Grid-Connected PV System", University of Technology, Malaysia, IEEE, pp. 114-119, 2011.

[12] Hussain S. Maraud, "Design and Implementation of an Intelligent Battery Charger for a Photovoltaic Power System", M.Sc. thesis presented to Mustansiriyah University, Iraq, 2016.

[13] Shen Guo. "The Application of Genetic Algorithms to Parameter Estimation in Lead-Acid Battery Equivalent Circuit Models", M.Sc. thesis presented to the University of Birmingham, The United Kingdom, 2010.

[14] Henry J. Zhang. "Basic Concepts of Linear Regulator and Switching Mode Power Supplies", Analog Devices, Inc., The United States of America, 2013.

[15] Dr. Muhammad H. Rashid. "Power Electronics Circuits, Devices and Applications", Fourth Edition, Pearson Education Limited, The United States of America, 2014.

Int J Pow Elec \& Dri Syst Vol. 11, No. 1, Mar 2020 : 275 - 283 
[16] Hussain A. Attia, Fernando delAma Gonzalo, "Stand-alone PV system with MPPT function based on fuzzy logic control for remote building applications", International Journal of Power Electronics and Drive System (IJPEDS), Vol. 10, No. 2, pp. 842-851, 2019.

[17] Khadidja Saidi, Mountassar Maamoun, M'hamed Bounekhla, "A new high performance variable step size perturband-observe MPPT algorithm for photovoltaic system", International Journal of Power Electronics and Drive System (IJPEDS), Vol. 10, No. 3, pp. 1662-1674, 2019.

[18] Siddharthan, Niranjana, Baskaran Balasubramanian, "Performance evaluation of SEPIC, Luo and ZETA converter", International Journal of Power Electronics and Drive System (IJPEDS), Vol. 10, No. 1, pp. 374-380, 2019.

[19] Private Communications with Asst. Prof. Sahib M. Mahdi, the head of Material Engineering Department at Mustansiriyah University-Iraq, and chief engineer Sabah M. Ali at Cathodic Protection Unit in Al-Quds Gas Station-Iraq.

[20] Wyatt, Brian S., Eur Ing, C. Eng, FICorr MIM, and FCS FIHT. "Advanced systems of overline assessment of coatings and cathodic protection.", In UMIST Cathodic Protection Conference, Manchester, 2003.

[21] Cicek, "Corrosion Engineering and Cathodic Protection Handbook With Extensive Question and Answer Section", First Edition, John Wiley \& Sons, 2017

[22] Von Baeckmann, Walter, Wilhelm Schwenk, and Werner Prinz. "Handbook of cathodic corrosion protection", Third Edition, Gulf Publishing Company, 1997.

[23] Revie, R Winston. "Corrosion and Corrosion Control: An Introduction to Corrosion Science and Engineering", John Wiley \& Sons, Canada, 2008.

[24] Qais Matti Alias, and Waleed H. Habeeb. "Design and Implementation of Cathodic Protection System for Cooling Water Pipeline to Al-Quds Gas Power Station", Diyala Journal of Engineering Sciences, Vol. 10, No. 2, pp. 1-11, 2017.

[25] Callister, William D., and David G. Rethwisch. "Materials science and engineering: an introduction", Vol. 7, John Wiley \& Sons, 2007. 